Published in: Journal of Ethnic and Migration Studies Vol. 33, No. 8 (2007), pp. 13231342

\title{
Class Position of Immigrant Workers in a Post-Industrial Economy: The Dutch Case
}

\author{
Erik Snel, Jack Burgers and Arjen Leerkes ${ }^{1}$
}

\begin{abstract}
In this paper, the issue of changing labour-market opportunities and the position of members of minority groups in advanced service economies is addressed, focusing on the Dutch case. We distinguish between two social hierarchies, one of traditional 'fordist' occupations and one of post-fordist occupations. Compared to the native Dutch, all immigrant groups are over-represented at the bottom of the labour market, both in the fordist and in the postindustrial hierarchy. Increased immigrant labour-market participation in the 1990s was accompanied by a strong rise in the number of flexible labour contracts. Native Dutch also work more frequently on flexible labour contracts, but not to the same extent as immigrants.

The lower occupational level of the Surinamese, Antilleans and other non-Western immigrants employed in post-industrial occupations can be attributed to their low educational level. This is not true, however, for Turks, Moroccans and other non-Western immigrants employed in fordist occupations. Their low occupational level cannot be completely explained by their low educational level. The effects of changes in the economic structure differ for ethnic groups, depending on their past employment, their cultural capital and the institutional framework in which they have to operate.
\end{abstract}

Keywords: Post-Industrial Economy; Immigrant Workers; Labour Market; Class Position; The Netherlands

\section{New Inequalities in the Post-Industrial Labour Market}

Like many other Western European countries, the Netherlands is faced with the question of what the prospects are for non-Western immigrants in an increasingly post-industrial labour market. Two factors are of importance here: the labour-market qualifications of immigrants coming from non-Western countries on the one hand and the kinds of job that are available in an increasingly knowledge-based economy on the other. As for the labour-market qualifications of non-Western immigrants, two tendencies are relevant. Although there is a growing heterogeneity within and between minority groups, many

\footnotetext{
${ }^{1}$ Erik Snel and Jack Burgers are respectively Assistant Professor of Sociology and Professor of Urban Studies in the Department of Sociology at Erasmus University, Rotterdam. Correspondence to: Dr E. Snel/Prof. J. Burgers, Dept of Sociology, Erasmus University, PO Box 1738, 3000 DR Rotterdam, The Netherlands. E-mail: snel@fsw.eur.nl; burgers@fsw.eur.nl. Arjen Leerkes is a PhD Candidate at the Amsterdam School for Social Science Research. Correspondence to: A. Leerkes, Amsterdam School for Social Science Research, Kloveniersburgwal 48, 1012 CX Amsterdam, The Netherlands. E-mail: a.s.leerkes@uva.nl
} 
members of such groups still have relatively low levels of professional and educational training. This is especially true for former guestworkers from Mediterranean countries, who were, after all, purposely recruited as unskilled labour for traditional Dutch industries. But postcolonial immigrants and immigrants from other non-Western countries (many of whom came to the Netherlands as asylum-seekers) are also often rather poorly educated, although there is greater variety when it comes to their labourmarket qualifications than in the guestworker groups.

In the sociological literature on the restructuring of the labour market in advanced economies, two more or less competing theories have been formulated as to the position of low-skilled minority or immigrant workers within contemporary labour markets (see Burgers and Musterd 2002). One theory (Hamnett 1996; Wilson 1987) states that the emerging post-industrial economy leads to an increasing professionalisation and upgrading of the labour market. As skilled and unskilled jobs in traditional industries gradually disappear, new jobs in the post-industrial service economy often require professional and academic training. As a consequence, labour market opportunities for unskilled or poorly skilled workers will diminish and they will increasingly be excluded from the labour market. In this perspective, the poorly educated represent an obsolete labour supply in post-industrial economies (Cantillion et al. 2003; Rosanvallon 2000; Wilson 1987, 1996). Employment prospects of immigrant workers, then, will depend heavily on how quickly and to what extent they catch up with the indigenous population in terms of the relevant cultural capital, especially educational skills.

A competing theory on the character of post-industrial labour markets argues that they are not upgrading, but polarising (Esping-Andersen 1993; Fainstein et al. 1991; Mollenkopf and Castells 1991; Sassen 2001). This theory suggests that there will be a growing number of jobs at both ends of the post-industrial labour market. So not only the number of professionals increases, but also the number of people working in low-skilled or unskilled service jobs. The assumption is that both the service industries (headquarters of transnational corporations, internationally operating banking and insurance companies, financial services etc.) and their well-paid employees generate a new demand for unskilled service work. The service industries generate and 'outsource' low-skilled service jobs in, for instance, cleaning, catering and security, and the new professional elite of the post-industrial economies creates low-skilled employment because of their need for personal services in their homes (cleaning, housekeeping, childcare, etc.) in restaurants and cafes, and in the urban 'fun industry'. As a result, not so much professionalisation, but polarisation is typical for the current post-industrial labour market. Esping-Andersen (1999) points to the rise of an 'unskilled service workers class' or a 'post-industrial service proletariat' in which women and immigrant workers are overrepresented. This point has been illustrated in Sassen's work on global cities: 'Blacks and Third World immigrants in New York are disproportionately concentrated in lowerpaying, more traditional service industries, notably health and social services and in the low-paying jobs of the producer services' (Sassen 2001: 324). The same is true, she argues, for other global cities.

The two theories posit different forms of social inequality as typical for contemporary post-industrial economies. For the first theory, the main inequality is one between workers with steady positions in the labour process and persons excluded from the labour market. The second theory points out new inequalities in the labour market 
between well-paid professional workers on the one hand and the new 'service proletariat' with often badly paid and insecure jobs that offer little opportunity for upward social mobility on the other (cf. Newman 2000). This paper examines the labour-market position of immigrant workers in the emerging advanced service economies, focusing on the Dutch case. Using Dutch Labour Survey data for 1992 and 1999, we analyse the changing labour-market position of immigrant and native Dutch workers against the background of the postindustrialisation of the Dutch economy. Using official labour survey data implies that we have to conform to the definition of 'immigrants' as used in these surveys. In the Dutch labour surveys of the 1990s, a person was considered to be an 'immigrant' when he or she was either foreign-born or did not have Dutch citizenship. Since this category mainly (although not exclusively) pertains to first-generation immigrants ${ }^{1}$ we will refer to them as 'immigrants' or 'immigrant workers'. Furthermore, official Dutch statistics distinguish between Western (from other EU countries, the USA, etc.) and non-Western immigrants. This paper focuses on non-Western immigrant workers (including those from the former Dutch colony of Surinam and from the Dutch Antilles). ${ }^{2}$

We will analyse the changing labour-market position of non-Western immigrant workers and native Dutch workers by using the class scheme developed by EspingAndersen (1993). This scheme has mainly been used to study national labour-market developments but, as far as we are aware, has not yet been applied in studies addressing the labour-market position of immigrant workers. The pivotal point in this scheme is a distinction between two separate social hierarchies, one of which is linked to traditional 'fordist' occupations and the other to upcoming post-industrial occupations. ${ }^{3}$ The main advantage of Esping-Andersen's class scheme is that he does not position the new service occupations as 'middle class' in between managerial positions on the one hand and manual workers on the other (Steijn et al. 2000; Wright 1989) but as a social hierarchy on its own, with higher and lower positions. This enables us to examine whether there is a shift of non-Western immigrant workers from traditional fordist to the new postindustrial occupations. If this is so, we can examine where these immigrant workers end up in the post-industrial hierarchy: at the bottom of the post-industrial labour market (unskilled service work) or also in middle-class service occupations: technicians, semiprofessionals (see Figure 1).

Figure 1. Classes according to Esping-Andersen (1993)

\begin{tabular}{|l|l|}
\hline The fordist hierarchy & The postindustrial hierarchy \\
\hline a Managers and proprietors & a Professionals and scientists \\
b Clerical, administrative and sales workers & b Technicians and semi-professionals \\
c Skilled/crafts manual production workers & c Skilled service workers \\
d Unskilled and semi-skilled manual & d Unskilled service workers ("service \\
production workers & proletariat") \\
\hline
\end{tabular}

Our empirical analysis is presented in the next three sections of this paper. The first section presents an overview of the main developments in the Dutch labour market in the 1990s. Then follows an analysis of the changing labour-market position of native Dutch and non-Western immigrant workers in terms of Esping-Andersen's classscheme. In the third section we assess to what degree the labour-market position of immigrant workers is 
the result of their educational level, or if other factors play a role as well. We conclude with a discussion of our central findings.

\section{The Dutch Labour Market in the 1990s}

In the 1990s, the Netherlands witnessed a decade of economic prosperity and rapid job growth. As various studies showed, immigrant groups were also able to benefit from this favourable trend in the Dutch economy (SCP 2003; Snel et al. 2006). In 1994, less than 30 per cent of Turkish and Moroccan residents of working age held formally paid jobs. Eight years later, in 2002, the net labour-market participation of Turks and Moroccans had risen to about 45 per cent. The net labour market participation of postcolonial migrants (Surinamese and Antilleans) even approximated that of the native Dutch (about 60 to 70 per cent in 2002; cf. SCP 2003). ${ }^{4}$

Unemployment is another indicator of the improved labour-market position of non-Western immigrants in the Netherlands during the 1990s. In the middle of the decade, unemployment of non-Western immigrants was still extremely high (around 30 per cent for Turks and Moroccans, 20 per cent for Surinamese and Antilleans). In 2001, unemployment in all these immigrant groups dropped spectacularly to 10 per cent or less. ${ }^{5}$

In this article we are especially interested in the 1990s, the epoch of economic prosperity and rapid job growth in the Netherlands. In this era of booming economy, not only were job opportunities on the rise, but the number of non-Western immigrant workers in the Netherlands rose spectacularly, both as a percentage of the immigrant population and in absolute terms (the growth in absolute numbers of non-Western immigrant workers is documented in the row totals at the bottom of Table 1). In such a period, the question of which migrant groups benefit from what kind of job opportunities can best be answered, because their socio-economic position can expected to be blocked more by their capabilities than by the economic tide.

Given the increased number of non-Western immigrant workers in the Netherlands, the question arises as to what types of occupation were characteristic for these groups towards the end of the 1990s. Were they still primarily working in traditional fordist occupations or is a shift observable towards post-industrial occupations? And if so, what positions do non-Western immigrant workers have in the post-industrial hierarchy? Were they primarily poorly educated members of a growing service proletariat, or could they also be found in the higher echelons of post-industrial occupations?

\section{The Changing Class Positions of Immigrant Workers}

In this section we describe the changing occupational class position of non-Western immigrant workers and native Dutch workers in terms of Esping-Andersen's (1993) class categories. As noted earlier, the core of this scheme is a distinction between two types of occupation, 'fordist' and 'post-industrial', each with its own hierarchy. The question is where non-Western immigrant workers are to be found in this scheme, in what types of 
job and at what level. Before we focus on specific population categories (immigrants and native Dutch workers), let us first see the extent to which the Netherlands has advanced in the direction of a post-industrial occupational structure. Table 1 distinguishes three types of occupation: agrarian, fordist and post-industrial. The table makes clear that, at the end of the 1990s, the Dutch labour market could not be classified as post-industrial: more than half of all Dutch workers were active in fordist occupations. Nevertheless, we see a slow but steady shift from fordist to postindustrial occupations. Earlier research showed that only in the Dutch capital, Amsterdam, is more than half of the working population active in post-industrial occupations (Steijn et al. 2000).

Table 1 Class position of native Dutch and immigrant workers* in the Netherlands, 1992 and 1999 (between brackets: ratio with native Dutch (native Dutch =1)

\begin{tabular}{|c|c|c|c|c|c|c|c|c|}
\hline & \multicolumn{2}{|c|}{ Native Dutch } & \multicolumn{2}{|c|}{$\begin{array}{r}\text { Turks and } \\
\text { Moroccans }\end{array}$} & \multicolumn{2}{|c|}{$\begin{array}{r}\text { Surinamese and } \\
\text { Antilleans }\end{array}$} & \multicolumn{2}{|c|}{$\begin{array}{r}\text { Other non- } \\
\text { Western } \\
\text { immigrants } * *\end{array}$} \\
\hline & 1992 & 1999 & 1992 & 1999 & 1992 & 1999 & 1992 & 1999 \\
\hline Agrarian & 5,0 & 3.9 & $x$ & $x$ & $x$ & $x$ & $x$ & 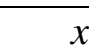 \\
\hline Managers & 8.2 & 9.6 & $\mathrm{x}$ & $\mathrm{x}$ & 6.4 & 5.6 & $\mathrm{x}$ & 8.2 \\
\hline Clerical & 15,0 & 14.4 & 7.7 & 5.8 & 21.2 & 20.3 & $\mathrm{x}$ & 9,0 \\
\hline Sales & 8.8 & 9.3 & $\mathrm{x}$ & 5.8 & $\mathrm{X}$ & 4.1 & $\mathrm{x}$ & 7.3 \\
\hline Skilled manual & 11.9 & 10.4 & 16.3 & 14.2 & 8,0 & 7.9 & 10.8 & 8.3 \\
\hline Unskilled manual & 11.3 & 11,0 & 43.4 & 35.5 & 16.6 & 14.4 & 12.1 & 18.3 \\
\hline Total fordist & 55.3 & 54.6 & 73.2 & 65.0 & 56.7 & 52.4 & 46.4 & 51.2 \\
\hline Professionals & 11.3 & 13 & $\mathrm{X}$ & $\mathrm{x}$ & 9.1 & 8.9 & 16.5 & 13.9 \\
\hline $\begin{array}{l}\text { Semi-professional } \\
+ \text { technicians }\end{array}$ & 15.9 & 17 & $\mathrm{x}$ & 7.0 & 16.8 & 17.7 & 13.8 & 9.5 \\
\hline Skilled service & 4.9 & 4.7 & $\mathrm{X}$ & $\mathrm{x}$ & $\mathrm{X}$ & 5.7 & $\mathrm{x}$ & 5.5 \\
\hline Unskilled service & 7.7 & 6.7 & 17.2 & 16.7 & 11.9 & 14.8 & 16.9 & 18.3 \\
\hline $\begin{array}{l}\text { Total post- } \\
\text { industrial }\end{array}$ & 39.8 & 41.5 & 24.2 & 30.8 & 42.5 & 47.1 & 52.6 & 47.2 \\
\hline Total (x 1000) & 5,162 & 5,966 & 69 & 91 & 88 & 123 & 53 & 105 \\
\hline $1992=100$ & 100 & 116 & 100 & 132 & 100 & 140 & 100 & 198 \\
\hline $\begin{array}{l}\text { * foreign-born or } \\
* * \text { Including ethn } \\
x=\text { Number of re } \\
\text { Source: Statistics } \\
\text { calculations) }\end{array}$ & $\begin{array}{l}\text { nation } \\
\text { scent }\end{array}$ & Labou & ve & 3B) & 92 an & $\begin{array}{l}\text { made } \\
99(\mathrm{al}\end{array}$ & ors' & \\
\hline
\end{tabular}

We are interested, however, in differences in occupational and class position between native Dutch and non-Western immigrant workers. The number of non-Western immigrant workers in agrarian occupations is so small that no reliable data are available, which is why we exclude this sector from the following analyses. We distinguish between three non-Western immigrant groups: Turks and Moroccans; Surinamese and Antilleans; and other non-Western immigrants.6 We will compare the changing labour-market 
positions of these immigrant groups with those of native Dutch workers. In Table 2, data are presented which differentiate between men and women.

Table 1 shows sizeable differences among the three non-Western immigrant categories. Turks and Moroccans, the former guestworkers and their families, clearly lag behind the general trend towards post-industrialisation of the occupational structure in the Netherlands. In 1992, almost three-quarters of all employed Turks and Moroccans worked in a fordist occupation, as did two-thirds in 1999. This is not only true for Turkish and Moroccan male workers, as might be expected from their guestworker background, but also for Turkish and Moroccan female workers (see Table 2). The situation was quite different for the other non-Western immigrant groups. They were much more part of the trend towards post-industrialisation of the occupational structure. In both years, a higher than average percentage of the working population from Surinam, the Antilles and other non-Western countries was employed in post-industrial occupations. As can be seen in Table 2, this mainly held true for female workers of these immigrant groups. Whereas about half of all native Dutch female workers were employed in post-industrial occupations, this was true for 59 per cent of the Surinamese and Antillean female workers and for 57 per cent of those from other non-Western countries. Only 43 per cent of Turkish and Moroccan female workers were employed in postindustrial occupations, considerably lower than the percentages of female workers from any other category, but higher than the percentage of Turkish and Moroccan male workers. Of the latter category, only 27 per cent was employed in post-industrial occupations (see the data from 1999 in Table 2).

Table 2 Class position of native Dutch and non-Western immigrant* workers by gender, 1992 and 1999

\begin{tabular}{|l|l|l|l|l|l|l|l|l|}
\hline & \multicolumn{3}{|l|}{ The Dutch } & \multicolumn{2}{l}{$\begin{array}{l}\text { Turks and } \\
\text { Moroccans }\end{array}$} & \multicolumn{2}{l}{$\begin{array}{l}\text { Surinamese and } \\
\text { Antilleans }\end{array}$} & \multicolumn{2}{l|}{$\begin{array}{l}\text { Other non-Western } \\
\text { immigrants** }\end{array}$} \\
\hline & 1992 & 1999 & 1992 & 1999 & 1992 & 1999 & 1992 & 1999 \\
\hline Men & & & & & & & & \\
\hline Agrarian & 6.2 & 4.9 & $\mathrm{x}$ & $\mathrm{x}$ & $\mathrm{x}$ & $\mathrm{x}$ & $\mathrm{x}$ & $\mathrm{x}$ \\
\hline Managers & 10.4 & 12.0 & $\mathrm{x}$ & $\mathrm{x}$ & $\mathrm{x}$ & 9.5 & $\mathrm{x}$ & 9.8 \\
\hline clerical/sales & 16.0 & 15.8 & $\mathrm{x}$ & $\mathrm{x}$ & 20.5 & 15.3 & $\mathrm{x}$ & 11.4 \\
\hline $\begin{array}{l}\text { skilled / } \\
\text { unskilled } \\
\text { manual }\end{array}$ & 33.2 & 32.3 & 67.7 & 57.9 & 34.7 & 37.8 & 30.0 & 35.5 \\
\hline Total fordist & 59.7 & 60.0 & 77.5 & 68.7 & 63.8 & 62.6 & 49.4 & 56.7 \\
\hline $\begin{array}{l}\text { Professionals } \\
\text { semi-prof } \\
+ \text { +tech }\end{array}$ & 13.4 & 15.0 & $\mathrm{x}$ & $\mathrm{x}$ & 11.8 & 10.8 & 17.4 & 15.6 \\
\hline $\begin{array}{l}\text { skilled / } \\
\text { unskilled } \\
\text { service }\end{array}$ & 9.3 & 72.1 & $\mathrm{x}$ & $\mathrm{x}$ & 12.7 & 14.2 & $\mathrm{x}$ & $\mathrm{x}$ \\
\hline $\begin{array}{l}\text { Total post- } \\
\text { industrial }\end{array}$ & 34.2 & 35.0 & 14.9 & 18.7 & 10.4 & 11.3 & 21.1 & 20.0 \\
\hline Total & 100.0 & 100.0 & 100.0 & 100.0 & 100.0 & 100.0 & 100.0 & 100.0 \\
\hline
\end{tabular}




\begin{tabular}{|c|c|c|c|c|c|c|c|c|}
\hline \\
\hline \multicolumn{9}{|l|}{ Agrarian } \\
\hline Managers & 4.2 & 5.9 & $\mathrm{X}$ & $\mathrm{X}$ & $\mathrm{X}$ & $X$ & $\mathrm{x}$ & $\mathrm{x}$ \\
\hline clerical/sales & 38.0 & 35.6 & $\mathrm{X}$ & 25.4 & 33.0 & 34.1 & $\mathrm{x}$ & 25.6 \\
\hline $\begin{array}{l}\text { skilled / } \\
\text { unskilled } \\
\text { manual } \\
\end{array}$ & 5.1 & 4.9 & $\mathrm{X}$ & 26.3 & $\mathrm{x}$ & $\mathrm{X}$ & $\mathrm{x}$ & $\mathrm{x}$ \\
\hline Total fordist & 47.4 & 46.4 & 57.4 & 54.6 & 46.6 & 41.5 & 40.0 & 41.2 \\
\hline Professionals & 7.5 & 10.1 & $\mathrm{x}$ & $\mathrm{x}$ & $\mathrm{x}$ & $\mathrm{x}$ & $\mathrm{x}$ & $\mathrm{x}$ \\
\hline $\begin{array}{l}\text { semi-prof } \\
+ \text { tech }\end{array}$ & 23.8 & 24.3 & $\mathrm{x}$ & $\mathrm{x}$ & 22.6 & 21.4 & $\mathrm{x}$ & 15.5 \\
\hline \begin{tabular}{|l} 
skilled / \\
unskilled \\
service \\
\end{tabular} & 18.5 & 16.7 & 34.1 & 23.0 & 25.2 & 30.3 & $\mathrm{x}$ & 30.7 \\
\hline $\begin{array}{l}\text { Total post- } \\
\text { industrial }\end{array}$ & 49.8 & 51.1 & 41.1 & 42.8 & 53.1 & 58.5 & 60.0 & 56.8 \\
\hline Total & 100 & 100.0 & 100 & 100.0 & 100 & 100.0 & 100 & 100.0 \\
\hline \multicolumn{9}{|c|}{$\begin{array}{l}* \text { Foreign-born of non-nationals } \\
* * \text { including ethnic origin unkno } \\
\mathrm{x}=\text { number of observations too }\end{array}$} \\
\hline
\end{tabular}

In addition to the type of occupation in which non-Western immigrants work - fordist or post-industrial - the occupational level is also important. Are non-Western immigrant workers still concentrated at the bottom of the labour market or do they exhibit an increasingly even distribution throughout the occupational structure? And does this differ between both social hierarchies?

Again, there are remarkable differences between the non-Western immigrant groups. Turkish and Moroccan workers were strongly over-represented in the unskilled occupations in both years, although there is an unmistakable reduction over time. In 1992, more than 60 per cent of the employed Turks and Moroccans worked in unskilled occupations (fordist or post-industrial); seven years later this was true for just 50 per cent. Also, Turkish and Moroccan workers in post-industrial occupations are often employed in unskilled work. Only in 1999 did a notable percentage of them work at a semiprofessional level. Turkish and Moroccan female workers are also over-represented in unskilled jobs, but to a somewhat lesser extent than Turkish and Moroccan males. In 1999, more than three-quarters of all Turkish and Moroccan male workers were employed in skilled or unskilled work (either in fordist or in post-industrial occupations), as were almost half (49 per cent) of all Turkish and Moroccan female workers.

Surinamese, Antillean and other non-Western immigrant workers are much less concentrated at the bottom of the labour market. Certainly they, too, work in unskilled occupations more often than the native Dutch, but they can also be found in higherqualified occupations. In 1999, 20 per cent of the Surinamese and Antilleans were employed in clerical occupations, 9 per cent in professional service occupations and 18 per cent in middle-level service professions as semi-professionals or technicians. 
Surinamese and Antillean women especially are known in the Netherlands as an immigrant category with a high labour participation rate. The data in Table 2 show that 55 per cent of all Surinamese and Antillean female workers are employed in middle-level occupations (clerical, sales, semi-professional and technical), only slightly fewer than native Dutch female workers (60 per cent). Surinamese and Antillean female workers are also often employed in skilled and unskilled service work ( 30 per cent), to a greater extent than Turkish and Moroccan female workers. Finally, it is striking how many working people from other non-Western countries were employed at the highest levels: 8 per cent of all other non-Western immigrant workers were employed as managers and 14 per cent in professional service occupations (see Table 1). This last percentage is even higher than the average for the Dutch working population.

Another question is whether or not over-representation of non-Western immigrant workers at the bottom of the labour market is stronger in the traditional, fordist occupations than in the post-industrial hierarchy. In order to answer this question, we have calculated the percentage of all the working people in each immigrant group in both occupational hierarchies who were employed in an unskilled occupation (Table 3, data for 1999). The outcomes do not show marked differences between the various population categories. The percentage of native Dutch workers in unskilled occupations in the fordist hierarchy is somewhat higher than in the post-industrial one. With Surinamese, Antillean and other non-Western immigrant workers, the situation is precisely the opposite: the percentage of them employed in unskilled occupations is somewhat higher in the postindustrial hierarchy than in the fordist. Turkish and Moroccan workers are evenly employed in unskilled occupations in both hierarchies. These figures indicate that the post-industrialisation of the occupational structure seems to be accompanied by a tendency towards upgrading for the native Dutch, but not for non-Western immigrant workers.

A last issue concerns the type of labour contracts that native Dutch and immigrant workers have in both occupational hierarchies. It is often assumed that low-skilled service work is characterised by temporary or flexible jobs (Esping-Andersen 1993; Newman 2000). Table 4 shows the percentage of native Dutch and non-Western immigrant workers in both occupational hierarchies employed in so-called 'flexible labour relations' defined as temporary contracts or jobs with no fixed working hours together with a sharp rise in the percentage of these flexible labour relations in the 1990s. This holds true for native Dutch and immigrants alike, regardless of their kind of occupation (fordist or post-industrial, high or low). The table also shows that immigrant workers are more often employed in flexible labour relations than native Dutch workers, with one notable exception: immigrant workers in skilled and unskilled ('low') service jobs. In other words, native Dutch skilled or unskilled service workers are employed in flexible labour relations just as often as non-Western immigrant workers in the same occupations. In all other kinds of occupation, non-Western immigrant workers are 1.5_3 times more often employed in flexible labour relations than native Dutch workers. Interestingly, the differences between native Dutch and non-Western immigrant workers are considerably greater in the traditional fordist hierarchy than in the post-industrial. Particularly in low-fordist occupations (skilled and unskilled manual work), immigrants very frequently work in flexible labour relations. 
Table 3 Class position of native Dutch and non-Western immigrant* workers, 1992 and 1999 (percentage data)

\begin{tabular}{|c|c|c|c|c|c|c|c|c|}
\hline & \multicolumn{2}{|c|}{ The Dutch } & \multicolumn{2}{|c|}{$\begin{array}{l}\text { Turks and } \\
\text { Moroccans }\end{array}$} & \multicolumn{2}{|c|}{$\begin{array}{l}\text { Surinamese and } \\
\text { Antilleans }\end{array}$} & \multicolumn{2}{|c|}{$\begin{array}{l}\text { Other non- } \\
\text { Western } \\
\text { immigrants** }\end{array}$} \\
\hline & 1992 & 1999 & 1992 & 1999 & 1992 & 1999 & 1992 & 1999 \\
\hline Managers & 14.9 & 17.5 & $\mathrm{x}$ & $\mathrm{X}$ & 11.3 & $\mathrm{X}$ & $\mathrm{X}$ & 16.0 \\
\hline Clerical & 27.2 & 26.3 & 10.5 & 8.9 & 37.3 & 38.8 & $\mathrm{X}$ & 17.6 \\
\hline Sales & 15.9 & 17.0 & $\mathrm{x}$ & 8.9 & $\mathrm{X}$ & 7.9 & $\mathrm{X}$ & 14.3 \\
\hline skilled manual & 21.5 & 19.0 & 22.2 & 21.8 & 14.2 & 15.0 & 23.3 & 16.3 \\
\hline unskilled manual & 20.5 & 20.1 & 59.2 & 54.6 & 29.2 & 27.5 & 26.2 & 35.8 \\
\hline Total fordist & 100.0 & 100.0 & 100.0 & 100.0 & 100.0 & 100.0 & 100.0 & 100.0 \\
\hline Professional & 28.4 & 31.4 & $\mathrm{x}$ & $\mathrm{X}$ & 21.5 & 18.8 & 31.4 & 29.4 \\
\hline semi-p+tech & 39.9 & 41.0 & $\mathrm{x}$ & 22.8 & 39.6 & 37.6 & 26.1 & 20.2 \\
\hline skilled service & 12.3 & 11.4 & $\mathrm{x}$ & $\mathrm{X}$ & $\mathrm{X}$ & 12.2 & $\mathrm{~S}$ & 11.6 \\
\hline unskilled service & 19.4 & 16.2 & 70.8 & 54.1 & 28.0 & 31.4 & 32.1 & 38.7 \\
\hline $\begin{array}{l}\text { Total post- } \\
\text { industrial }\end{array}$ & 100.0 & 100.0 & 100.0 & 100.0 & 100.0 & 100.0 & 100.0 & 100.0 \\
\hline $\begin{array}{l}* \text { Foreign-born of } \\
* * \text { including ethni } \\
\mathrm{x}=\text { number of ob } \\
\text { Source: Statistics }\end{array}$ & $\begin{array}{l}\text { f non- } \\
\text { ic orig } \\
\text { servat }\end{array}$ & $\begin{array}{l}\text { als } \\
\text { kno }\end{array}$ & e & & & & & \\
\hline
\end{tabular}

Table 4: Percentage of native Dutch and non-Western immigrant* workers employed on flexible contracts, 1992 and 1999

\begin{tabular}{|l|l|l|l|l|}
\hline & $\begin{array}{l}\text { Native } \\
\text { Dutch }\end{array}$ & $\begin{array}{l}\text { Ethnic } \\
\text { minorities }\end{array}$ & $\begin{array}{l}\text { Native } \\
\text { Dutch }\end{array}$ & $\begin{array}{l}\text { Ethnic } \\
\text { minorities }\end{array}$ \\
\hline & 1992 & 1992 & 1999 & 1999 \\
\hline Fordist high & 4.1 & 3.8 & 8.2 & 16.5 \\
\hline Fordist low & 3.5 & 7.7 & 8.6 & 25.2 \\
\hline Post-industrial high & 4.7 & 7.9 & 6.3 & 10.4 \\
\hline Post-industrial low & 9.3 & 8.5 & 16.2 & 16.2 \\
\hline Sourc & & 9.3 &
\end{tabular}

Source: Statistics Netherlands, Labour Survey, 1992 and 1999 (our own calculations)

These results challenge the accepted view that temporary and flexible jobs are characteristic of the post-industrial service proletariat and that immigrant workers in lowskilled service jobs in particular are confronted with flexible labour relations. The opposite seems to be true. In particular immigrant workers in low-skilled manual jobs are - more than the average - employed on flexible labour contracts. Furthermore, the difference between native Dutch and immigrant workers with respect to job security in the fordist hierarchy is much larger than in the post-industrial. The explanation for the differences between the two hierarchies might be that job growth mainly occurred in the post-industrial labour market during the period of study. The tight labour market of the latter half of the 1990s may well have reinforced the position of immigrants on the post- 
industrial labour market so that they are now eligible for the same jobs as the Dutch, certainly at the bottom of the labour market.

The growing difference between the Dutch and immigrant workers as regards the percentage of flexible jobs in the traditional fordist sector might derive from precisely the opposite mechanism, i.e. further redundancies, especially in the regular, permanent job segment, leading to a further marginalisation of the labour market in this sector, so that only the weakest groups with very few other options continue to rely on this niche. It is only logical to assume that this pertains mainly to the former guestworkers, particularly Turks and Moroccans, whose limited mastery of the Dutch language offers them fewer opportunities in the service sector compared to Surinamese and Antilleans.

The main conclusion to be drawn from our analysis thus far is that there are considerable differences between the occupational positions of the various non-Western immigrant groups in the Netherlands. Turks and Moroccans are still strongly oriented towards the traditional fordist occupations and are highly over-represented there at the bottom of the labour market. This is true for both male and female workers. Surinamese, Antilleans and other non-Western immigrant workers, and particularly female workers within these groups, are more oriented towards postindustrial occupations. Overrepresented at the bottom of both occupational hierarchies (unskilled manual as well as unskilled service workers) but to a lesser extent than Turkish and Moroccan workers, Surinamese, Antilleans and other non-Western immigrant workers are also increasingly present in higher occupations. In other words, there is a gradual improvement in the immigrant labour market position in the sense that these groups are moving up into the more qualified occupations. In the post-industrial hierarchy, we see that, compared to the Dutch, the Surinamese and Antilleans are performing reasonably well at the middle and higher levels. Finally, the accepted view that flexible work is characteristic of low-skilled service work surprisingly seems not to be true. For non-Western immigrant workers, flexible labour relations are much more common in lower fordist occupations than in lower service occupations.

\section{Determinants of the Lower Class Position of Immigrants}

Despite their improved labour-market position, we can say that non-Western immigrants are still over-represented in unskilled occupations. Non-Western immigrant groups are employed 1.5_3 times as often as native Dutch in unskilled occupations. In the postindustrial hierarchy, the percentage of non-Western immigrant workers in unskilled occupations is even higher than in the traditional fordist occupations.

Is this over-representation of non-Western immigrant workers in the unskilled occupations the result of their poor educational levels, or do other factors play a role as well? In this section we will use multiple regression analyses to answer this question (see Table 5a and 5b). 8 Before doing so, we present some background information about the development of educational levels of native-Dutch persons and non-Western immigrants in the previous decade.

Figure 2 shows that non-Western immigrants in the Netherlands have strongly improved their educational level in the last decade, but are still lagging behind the native Dutch. The educational gap between them differs, however, for different groups. Turks 
and Moroccans clearly have the lowest educational levels. Although the share of poorly educated Turkish and Moroccan adults dropped from 80 per cent in 1996 to 60 per cent in 2004 , the number of poorly educated people in both immigrant groups is still very high (almost twice as high as in the native Dutch group). 9 In the other non-Western immigrant groups the share is much smaller and, accordingly, the educational gap with the native Dutch group is less wide. In 2004, the share of poorly educated Surinamese and Antillean adults decreased to 40 per cent, and of other non-Western immigrants to 37 per cent compared to 33 per cent in the native Dutch group.

Now we examine to what extent the lower occupational positions of non-Western immigrants, compared to the native Dutch, can be attributed to their lower educational levels. For each occupational hierarchy we have tested four different models. The first model demonstrates what we already know from our previous analyses; i.e. that nonWestern immigrant groups have lower class positions than the native Dutch reference category. This is true for both occupational hierarchies and for all non-Western immigrant groups, although for Turks and Moroccans to a much larger extent than for Surinamese, Antilleans and other non-Western immigrants. The explained variance of this first model, however, is very small $\left(\mathrm{R}^{2}=0.01\right)$.

Table 5a. Determinants of social position in fordist hierarchy (linear regression: beta coefficients)

\begin{tabular}{|c|c|c|c|c|c|c|c|}
\hline \multirow{2}{*}{\begin{tabular}{|l|} 
\\
(Constant)
\end{tabular}} & \multirow[t]{2}{*}{ Model 1 } & & \multirow{2}{*}{\multicolumn{2}{|c|}{ Model 2 }} & Model 3 & \multicolumn{2}{|l|}{ Model 4} \\
\hline & & & & & & & \\
\hline Turks / Moroccans & -0.10 & ** & $-0.05 *$ & $* *$ & $-0.04 * *$ & 0.01 & n.s. \\
\hline Surinamese / Antilleans & -0.02 & $* *$ & $-0.01 *$ & $*$ & $-0.01 *$ & 0.00 & n.s. \\
\hline Other non-Western immigrants & -0.03 & $* *$ & -0.03 & $* *$ & -0.04 ** & 0.02 & n.s. \\
\hline Educational level & & & $0.42 *$ & $* *$ & $0.41^{* *}$ & 0.42 & $* *$ \\
\hline Sex $($ female $=0)$ & & & & & $-0.20 * *$ & -0.20 & $* *$ \\
\hline Age in years & & & & & $0.17 * *$ & 0.17 & $* *$ \\
\hline $\begin{array}{l}\text { Educational level* Turks / } \\
\text { Moroccans }\end{array}$ & & & & & & -0.06 & $* *$ \\
\hline $\begin{array}{l}\text { Educational level* Surinamese / } \\
\text { Antilleans }\end{array}$ & & & & & & -0.01 & n.s. \\
\hline $\begin{array}{l}\text { Educational level* } \\
\text { other non-Western immigrants }\end{array}$ & & & & & & -0.06 & $* *$ \\
\hline $\mathrm{R}^{2}$ & 0.01 & & 0.18 & & 0.25 & 0.25 & \\
\hline
\end{tabular}

$* * \mathrm{p}<.01 / * \mathrm{p}<.05$ 
Table 5b. Determinants of social position in post-industrial hierarchy (linear regression: beta coefficients)

\begin{tabular}{|l|l|l|l|l|l|l|l|l|}
\hline & Model 1 & & Model 2 & & Model 3 & & Model 4 & \\
\hline (Constant) & & & & & & & & \\
\hline Turks / Moroccans & -0.09 & $* *$ & -0.02 & $* *$ & -0.02 & $* *$ & 0.03 & $*$ \\
\hline Surinamese / Antilleans & -0.05 & $* *$ & -0.01 & n.s. & 0.00 & n.s. & -0.02 & n.s. \\
\hline Other non-Western immigrants & -0.03 & $* *$ & -0.02 & $* *$ & -0.03 & $* *$ & -0.02 & n.s. \\
\hline Educational level & & & 0.68 & $* *$ & 0.66 & $* *$ & 0.66 & $* *$ \\
\hline Sex (female= 0) & & & & & 0.09 & $* *$ & 0.09 & $* *$ \\
\hline Age in years & & & & & 0.04 & $* *$ & 0.04 & $* *$ \\
\hline $\begin{array}{l}\text { Educational level* Turks / } \\
\text { Moroccans }\end{array}$ & & & & & & & -0.05 & $* *$ \\
\hline $\begin{array}{l}\text { Educational level* Surinamese / } \\
\text { Antilleans }\end{array}$ & & & & & & & 0.01 & n.s. \\
\hline $\begin{array}{l}\text { Educational level* } \\
\text { other non-Western immigrants }\end{array}$ & & & & & & & -0.01 & n.s. \\
\hline $\mathrm{R}^{2}$ & 0.01 & & 0.47 & & 0.48 & & 0.48 & \\
\hline
\end{tabular}

$* * \mathrm{p}<.01 / * \mathrm{p}<.05$

Figure 2. Educational levels of native Dutch and non-Western immigrant adults of working age, 15_64 years (1996_2004). (Source: Netherlands Statistics, Statline)

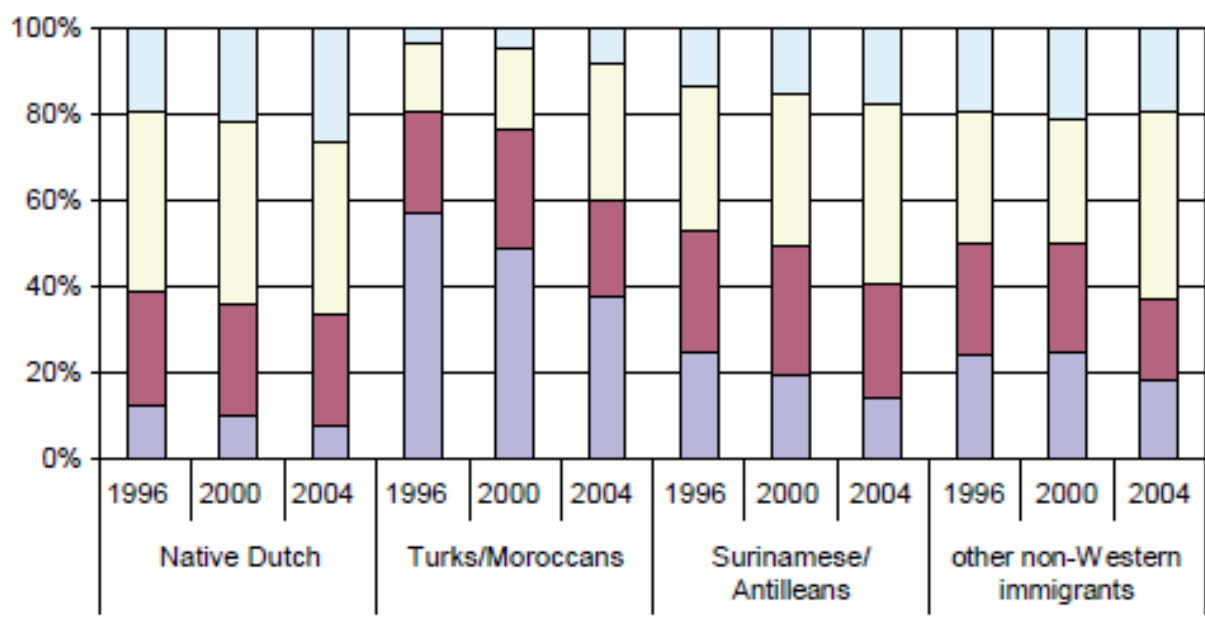

$\square$ only elementary $\square$ low-level $\square$ middle-level $\square$ high-level

In the second model, educational level is added and proves to be an extremely important factor in explaining the achieved occupational level of non-Western immigrants. Education plays an even larger role in the post-industrial hierarchy than in the fordist (cf. the b-coefficients of 0.68 and 0.42 respectively). However, the second model also shows that the lower educational levels of immigrant workers alone do not explain their lower occupational position. Belonging to an immigrant group still has a significant 
independent effect on the achieved occupational level, with the exception of the Surinamese and Antilleans in the post-industrial hierarchy. This last finding is highly relevant. It shows that, for the more successful immigrant groups, as the Surinamese and Antilleans certainly are, education and not ethnic background (or discrimination) is the main explanation of the achieved occupational position (see also Ode 2002: 96). Our analysis also shows that education is more important in the post-industrial hierarchy in explaining the occupational attainment of successful immigrant groups than in the traditional fordist hierarchy. The explained variance of the second model is much higher than the first, especially in the post-industrial hierarchy $\left(R^{2}=0.18\right.$ and 0.47 respectively).

In the third model, age and sex are added, but these variables make hardly any difference. The fourth model checks for possible interaction effects. It would be possible, for instance, for education to work out differently for different immigrant groups, and this indeed appears to be the case. After controlling for interaction effects, the differences in achieved occupational levels of all immigrant groups with the Dutch reference category disappear. We do, however, see weak but statistically significant interaction effects of immigrant background and educational level. This mainly holds true for Turks and Moroccans and to a lesser extent for other non-Western immigrants, but only in the fordist hierarchy. In combination with the findings of the first two models, this leads to the overall conclusion that, in the fordist as well as in the post-industrial hierarchy, the lower occupational position of Turks and Moroccans can be explained by two factors: their lower educational level and the fact that they apparently benefit less from a higher educational level than other groups. The same also holds true of other non-Western immigrant workers in the fordist hierarchy. This may be the result of labour-market discrimination or of other characteristics that were not included in our analysis (for instance, Dutch language skills, limited motivation, lack of access to formal and informal networks which provide job opportunities, etc.).

We do not see interaction effects of this kind in the case of the Surinamese and Antilleans and other non-Western immigrants employed in the post-industrial hierarchy. Their lower occupational position can be explained almost completely by personal characteristics, mainly education.

We may conclude that, compared to the native Dutch, all non-Western immigrant groups are over-represented at the bottom of the labour market in the fordist as well as the post-industrial hierarchies. However, the reason differs for each immigrant group. The lower occupational level of the Surinamese, Antilleans and other non-Western immigrants employed in post-industrial occupations can be attributed to their low educational level. In other words, if they had had more education, they would have higher occupational positions. This is not true, however, for Turks, Moroccans and other nonWestern immigrants employed in fordist occupations. Their low occupational level can largely, but not completely, be explained by their low educational level. These groups benefit less from their education than do native Dutch. In other words, they do not manage to reach the same occupational level as native Dutch workers with a comparable education. 


\section{Conclusions}

Firstly we note that immigrants benefited to a considerable extent from the favourable economic conditions in the late 1990s in the Netherlands. In this period of strong job growth, there was a sharp fall in their unemployment rates. Although the labour-market participation of certain immigrant groups, particularly Turks and Moroccans, is still relatively low, immigrants overall have been able to reduce their lag compared to the Dutch. In this paper we tried to establish the labour market position of immigrants. We looked at both the job level of immigrant workers and the types of occupation they have. Our most important finding is that there are striking differences among the immigrant groups. Turks and Moroccans (the former guestworkers)are clearly lagging behind the general trend towards the postindustrialisation of the occupational structure. In 1999, two-thirds of the employed Turks and Moroccans were still working in a fordist occupation. Strikingly enough, not only are Turkish and Moroccan men still strongly over-represented in the traditional fordist occupations, but the same holds true of Turkish and Moroccan women. Surinamese, Antilleans and other non-Western immigrant workers are employed more often than average in post-industrial occupations. As might be expected, this holds true more of the women than the men in these groups. A logical explanation would be that the former guestworkers are more oriented towards the traditional industries, the sector they started out in when they first arrived: a case of path dependency, as is also observed in American cities (cf. Waldinger 1996).

As regards occupational level, there is a strong concentration at the bottom of the labour market, especially among Turks and Moroccans. At the end of the 1990s, more than half the employed Turks and Moroccans still worked in unskilled jobs. This is true for men as well as women, and for the fordist and the post-industrial occupational hierarchies. Turks and Moroccans employed in post-industrial occupations were even more strongly concentrated at the bottom of the occupational hierarchy than their compatriots in fordist occupations. Surinamese and Antillean workers are, however, less likely to be concentrated at the bottom of the labour market. In fordist and post-industrial occupations alike, they have also entered the middle occupational levels. Other nonWestern immigrants exhibit a somewhat polarised occupational structure. Not only are they over-represented in the unskilled professions, but also, strikingly enough, many of them work in the higher echelons of the occupational hierarchy as managers or professionals.

A poor educational level is the most important explanation for the immigrant concentration at the bottom of both the occupational hierarchies. More education leads to a higher occupational level. Here again, there are differences between the various immigrant groups. The low occupational level of the Surinamese, Antilleans and other non-Western immigrants employed in post-industrial occupations can be completely attributed to their low educational level. This is not the case, however, for Turks, Moroccans and other non-Western immigrants employed in fordist occupations. Apparently, they benefit less, in terms of occupational level, from higher education than the Dutch or other immigrant groups do.

Finally, we see that increased immigrant labour-market participation in the 1990s was accompanied by a strong rise in the number of flexible labour contracts. The Dutch also now work more frequently on flexible labour contracts, but not to the same extent as 
immigrants. Strikingly enough, this holds true not only for low-level occupations, but for high-level ones as well, particularly in the fordist hierarchy. Native Dutch in low-level post-industrial occupations work just as frequently on flexible labour contracts as immigrants in these occupations do. Our findings seem to corroborate the thesis developed by Burgers and Musterd (2002) that the effects of changes in the economic structure differ for ethnic groups, depending on their past employment, their cultural capital and the institutional framework in which they have to operate.

What are the policy implications of our analysis? We note that in the near future, even though educational levels of immigrants will be rising, their labour-market chances will strongly depend on the extent to which they succeed in entering unskilled service occupations. In the United States, immigrants and ethnic minorities are indeed increasingly joining the ranks of the post-industrial service proletariat, but the question is whether this is or will also be the case in the Netherlands (cf. Veenman 2002). In today's Dutch institutional setting, the personal service sector is not growing at the same spectacular pace as in the United States. This is one reason why the Dutch economy still is not really post-industrial. However, the percentage of postindustrial occupations did gradually increase in the 1990s. Since there was a fall in the number of low-level industrial jobs, poorly educated immigrants are all the more dependent on low-level service jobs. As we note, however, different immigrant groups have different access to this segment of the labour market. The Surinamese, Antilleans and immigrants from other non-Western countries have succeeded in entering lowlevel service occupations; as a result of their improved performance in the educational field, they have also succeeded in entering middle- and higher-level jobs in the service economy. Turks and Moroccans are still strongly oriented towards low-level industrial jobs. The fewer jobs of this kind that are left in the economy, the more they will also be forced to focus on the service economy if large-scale and long-term unemployment is to be avoided.

\section{Notes}

[1] Also second-generation immigrants. Persons born in the Netherlands of foreign-born parents were counted as 'immigrants' but only when they have non-Dutch citizenship. In practice, most second-generation immigrants in the Netherlands have Dutch citizenship and were therefore counted as native Dutch. In the late 1990s these definitions of 'immigrants' in the Dutch labour surveys were changed. In recent versions of the survey both first- and second-generation immigrants are counted as 'immigrants' or 'allochthonous' as they are called in Dutch official statistics. Since we make use of older data of the Dutch Labour Survey (1992 and 1999) we have to stick to the old definitions of 'immigrants' (foreign-born or non- Dutch citizenship). For more on these definitions see Snel et al. (2006).

[2] As already noted, this paper is based on a secondary analysis of data from the Dutch Labour Survey, conducted by 'Netherlands Statistics' (in the rest of the paper we refer to the Dutch acronym 'CBS'). The Labour Survey is conducted every year among more than 90,000 respondents and incorporates weighting factors in such a way that the findings can be generalised to the Dutch working population at large. We use data for 1992 and 1999 in order to track changes in the types of job and class positions of native Dutch and immigrant workers. We rearranged the occupational data of the respondents in Esping-Andersen's class categories (Steijn et al. 2000). 
[3] To grasp Esping-Andersen's argument one should keep in mind that the distinction between the traditional, fordist hierarchy on the one hand and the emerging, post-industrial hierarchy on the other is not determined by the economic sector in which one works (manufacturing versus service industries), but by the kind of job one holds.

[4] 'Net labour participation' refers to the number of formally employed persons (at least 12 hours a week) as a percentage of the total population of working age (15_64 years). The reader should keep in mind that these more recent statistics use the new definition of minorities, counting both first- and second-generation immigrants in the minority or immigrant population.

[5] Unemployment among the native Dutch fell as well, to around 3 per cent in 2001. This implies that unemployment in non-Western immigrant groups was still three times as high in 2001 as in the mid-1990s.

[6] In our statistical analyses we had to take different non-Western immigrant groups together because of the relatively small numbers of respondents from these immigrant groups. The category 'other non-Western immigrants', of course, is more heterogeneous than the other two immigrant categories, and includes many non-Western immigrants who arrived in the Netherlands as asylum-seekers.

[7] Due to the limited number of respondents, at this point in the analysis it is no longer possible to distinguish between the various immigrant groups. Similarly, due to the limited number in each class, only four class positions are distinguished, fordist high (managers, clerical and sales), fordist low (skilled and unskilled manual labour), post-industrial high (professionals, semiprofessionals and technicians) and post-industrial low (skilled and unskilled service class). [8] We used linear regression analyses, although the dependent variable (position in a social hierarchy) is, of course, an ordinal and not an interval variable. Hence, from a purely methodological angle, we should have used ordinal instead of linear regression. We eventually chose the latter because it is relatively easy to explain its results to nonstatisticians, while ordinal regression analyses yielded comparable results.

[9] The reader should keep in mind that what is defined here as 'low-level education' is considered according to official EU standards to be an 'insufficient qualification to enter the labour market'.

\section{References}

Burgers, J. and Musterd, S. (2002) 'Understanding urban inequality: a model based on existing theories and an empirical illustration', International Journal of Urban and Regional Research, 26(2): 403_13.

Cantillion, B., Elchardus, M., Pestieau, P. and Van Parijs, P. (2003) De Nieuwe Sociale Kwesties. Antwerp and Apeldoorn: Garant.

Esping-Andersen, G. (1993) 'Post-industrial class structures: an analytical framework', in Esping- Andersen, G. (ed.) Changing Classes. Stratification and Mobility in Post-Industrial Societies. London: Sage, 7_31.

Esping-Andersen, G. (1999) Social Foundations of Post-Industrial Economies. Oxford: Oxford University Press.

Fainstein, S., Gordon, I. and Harloe, M. (eds) (1991) Divided Cities. New York and London in a Contemporary World. Oxford: Blackwell.

Hamnett, C. (1996) 'Why Sassen is wrong: a response to Burgers', Urban Studies, 33(1): 107_10.

Mollenkopf, J.H. and Castells, M. (eds) (1991) Dual City. Restructuring New York. New York: Russell Sage Foundation.

Newman, K. (2000) No Shame in my Game: The Working Poor in the Inner City. New York: Vintage Books. 
Ode, A. (2002) Ethnic-Cultural and Socio-Economic Integration in the Netherlands: A Comparative Study of Mediterranean and Caribbean Minority Groups. Assen: Koninklijke Van Gorcum.

Rosanvallon, P. (2000) The New Social Question: Rethinking the Welfare State. Princeton: Princeton University Press (first printed 1995).

Sassen, S. (2001) The Global City: New York, London and Tokyo. Princeton: Princeton University Press.

SCP (2003) Rapportage minderheden 2003. The Hague: Social and Cultural Planning Bureau.

Snel, E., de Boom, J., Engberse, G. and Weltevrede, A. (2006) Migration and Migration Policies in the Netherlands. Dutch SOPEMI Report 2004. Rotterdam: Rotterdams Instituut voor Sociaalwetenschappelijk Beleids Onderzoek (RISBO).

Steijn, B., Snel, E. and van de Laan, L. (2000) 'Een postindustrie"le klassenstructuur? Het klassenschema van Esping-Andersen toegepast op Nederland, Amsterdam en Rotterdam', Sociologische Gids, 58(2): 77_94.

Veenman, J. (ed.) (2002) De Toekomst in Meervoud: perspectief op multicultureel Nederland. Assen: Koninklijke Van Gorcum.

Waldinger, R. (1996) Still the Promised City? African-Americans and New Immigrants in PostIndustrial New York. Cambridge, Mass: Harvard University Press.

Wilson, W.J. (1987) The Truly Disadvantaged: The Inner City, The Underclass and Public Policy. Chicago: University of Chicago Press.

Wilson, W.J. (1996) When Work Disappears. The World of the New Urban Poor. New York: Alfred A. Knopf.

Wright, E.O. (1989) 'A general framework for the analysis of class structure', in Wright, E.O. (ed.) The Debate on Class. London: Verso, 3_46. 